\begin{tabular}{|l|l|}
\hline El Capitán Berardo Giraldo o el mito del buen guerrillero & Titulo \\
\hline Caballero, Farouk - Autor/a; & Autor(es) \\
\hline $\begin{array}{l}\text { De Raíz Diversa. Revista Especializada en Estudios Latinoamericanos (Vol. 2 no. 3 } \\
\text { ene-jun 2015) }\end{array}$ & En: \\
\hline México D.F. & Lugar \\
\hline $\begin{array}{l}\text { Programa de Posgrado en Estudios Latinoamericanos, Universidad Nacional } \\
\text { Autónoma de México }\end{array}$ & Editorial/Editor \\
\hline 2015 & Fecha \\
\hline $\begin{array}{l}\text { Lenguaje; Guerrilleros; Movimiento guerrillero; Imaginarios sociales; Mitos; Caribe; } \\
\text { América Latina; Colombia; }\end{array}$ & Colección \\
\hline Artículo & Temas \\
\hline $\begin{array}{l}\text { "http://biblioteca.clacso.edu.ar/Mexico/ppel-unam/20160621050025/Caballero_Farouk_El_Capitan_Berardo_Giraldo_o_el_mito_del_buen } \\
\text { guerrillero.pdr" }\end{array}$ & Tipo de documento \\
\hline $\begin{array}{l}\text { Reconocimiento-No Comercial-Sin Derivadas CC BY-NC-ND } \\
\text { http://creativecommons.org/licenses/by-nc-nd/2.0/deed.es }\end{array}$ & Licencia \\
\hline
\end{tabular}

Segui buscando en la Red de Bibliotecas Virtuales de CLACSO http://biblioteca.clacso.edu.ar

Consejo Latinoamericano de Ciencias Sociales (CLACSO)

Conselho Latino-americano de Ciências Sociais (CLACSO)

Latin American Council of Social Sciences (CLACSO)

www.clacso.edu.ar

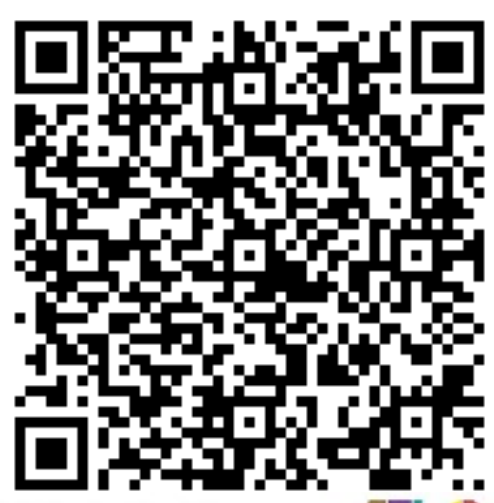

Consejo Latinoamericano de Ciencias Sociales

Conselho Latino-americano de Ciências Sociais 


\title{
El Capitán Berardo Giraldo o el mito del buen guerrillero
}

\author{
FAROUK CABALlero*
}

RESUMEN: el imaginario popular hace pensar que las guerrillas defienden al subalterno, al pobre, al desplazado por la violencia oficial y a sus tierras. Ese contexto hace que emerja un héroe épico moderno, con características especiales, ejemplarizantes en batalla y con autoridad incuestionable. De este modo, la literatura testimonial crea un personaje que se vuelve mito en su propia crónica. Además, el testimonio usa el lenguaje popular, la ascendencia liberal e indígena, la valentía guerrerista y el arte ecuestre para dialogar con las imágenes de los antiguos líderes insurgentes de Latinoamérica. Su voz construye un relato veraz. Los recursos literarios mitifican al líder guerrillero y, por lo tanto, es fundamental analizar su lenguaje, sus expresiones, la geografía marginal y su selección de anécdotas, con el propósito de rastrear la mitificación del buen guerrillero, en el testimonio del capitán.

Palabras Clave: Testimonio, mito, guerrillero y lenguaje.

ABstraCT: popular imagery suggests that the guerrillas defend the subaltern, the poor, the displaced by official violence and their lands. This context makes the emergence of a modern epic hero, with special features exemplary in battle and with unquestioned authority. Thus, testimonial literature creates a character who becomes myth in his own chronicle. Moreover, the testimony uses popular language, liberal and indigenous ancestry, warlike courage and equestrian Art to dialogue with the images of the former insurgent leaders in Latin America. His voice builds a true story. Literary devices mythify the guerrilla leader and, therefore, it is essential analyze their language, their expressions, the marginal geography and selection of stories, in order to trace the myth of the good fighter in the testimony of Captain Berardo Giraldo.

KEYWORDS: testimony, myth, guerrilla and language.

Recibido: 02 de septiembre de 2014. Aceptado: 01 diciembre de 2014 .

Mi mala fama era negra. Decían que a mí para matarme tenían que ponerme la bala en el ojo bueno, porque me salía de las emboscadas sin saber por dónde.

Berardo Giraldo

\footnotetext{
Doctorante en el Programa de Posgrado en Estudios Latinoamericanos de la UNAM. $<$ farouk1987@comunidad.unam.mx $>$
} 


\section{$\mathrm{E}$}

1 testimonio "Vida del capitán Berardo Giraldo, llamado el tuerto" es el texto más extenso y significativo del libro Siguiendo el corte. Relatos de guerras y de tierras $(1989)^{1}$ de Alfredo Molano. Allí, el protagonista del relato narra, en primera persona, su vida e injerencia en la conformación de las guerrillas del Llano en Colombia. Su configuración como personaje literario depende sólo de su voz. La selección de anécdotas, de cuentos, de escenas y de palabras, terminan por crear un personaje que toma la voz y enmarca su protesta social y su denuncia política, como el sentimiento generalizado del pueblo excluido por el gobierno central. El texto se trabaja desde un lenguaje propio del testimonio directo, que sin lugar a dudas, le envía un mensaje claro al lector, pues al narrarse desde un yo existente en el correlato histórico, el lector recibe una información que le da tintes inequívocos de veracidad al relato.

No obstante, esta precisión resulta válida para el lector ingenuo, porque al estudiar en detalle la configuración del relato y del mismo personaje que lo narra, las tensiones aumentan. El testimonio, al enmarcarse dentro de la dimensión estética literaria, también se inserta en las problemáticas propias del texto literario, por lo que su abordaje crítico debe hacerse con las herramientas de la crítica y teoría literarias; es decir, partiendo siempre desde el análisis textual, que se enriquece con una mirada interdisciplinar, pero que en esencia la contiene, pues la obra literaria es en sí misma una totalidad, en donde convergen correlato histórico, políticas, contexto socio-cultural, estilo narrativo del autor y dimensión estética del relato. En este orden de ideas, la hipótesis de lectura, que se desarrollará en ésta oportunidad, pretende demostrar que el personaje Berardo Giraldo se mitifica en su narración como arquetipo ideal de guerrillero. Sus palabras, sus acciones y el manejo del lenguaje permiten que Giraldo emerja en el relato como un mito que ejemplifica, justifica, valora, moraliza y representa la fundación ideal del movimiento guerrillero. Vale la pena mencionar que nuestra hipótesis de lectura no está directamente relacionada con una percepción en contra de las guerrillas colombianas, pero tampoco se enfoca en una visión laudatoria sobre su fundación y su rol dentro de la sociedad; todo lo contrario, puesto que el abordaje crítico y teórico permite entablar un diálogo respetuoso con una forma de hacer

1 Es pertinente acotar que aunque la primera edición del texto se publicó en 1989, la que se usará para este trabajo obedece a la edición de 2010. 
literatura que da cuenta de un proceso histórico, político y cultural que merece debatirse.

\section{MITO, ORÍGENES Y TESTIMONIO}

Las visiones que ofrecen los prólogos en los textos literarios determinan, en muchas ocasiones, la forma en la que el lector enfrentará la prosa. Este caso no es la excepción, pues el maestro de Alfredo Molano, Orlando Fals Borda, redacta el prólogo y hace comentarios que encauzan la lectura desde una perspectiva que ve con beneplácito que un intelectual, como llama a Molano, se acerque a la población rural y utilice la narrativa para dar cuenta de la tradición popular que pudo rescatar.

Además de esta perspectiva, Fals Borda alude a la relevancia del mito y su construcción como un elemento significativo en la literatura testimonial de Alfredo Molano, por eso afirma: "Molano se ha anticipado a la formación oral del mito en las regiones que estudió, aunque los elementos para ello estén ya dados en la sociedad llanera. No fue necesario esperar mil años para que nuestro Homero hallara su Pisístrato y quedaran por escrito las gestas de los antiguos" (Fals Borda, 2010: 20). Ligada a esta visión mítica, la hipótesis de lectura que se pretende trabajar va más allá de la labor del escritor, periodista, etnólogo, sociólogo que relata lo que escucha, pues este trabajo se centra en la figura del narrador. Para los intereses de la propuesta analítica Homero es importante, pero más relevantes son las palabras del Odiseo del Llano: el capitán Berardo Giraldo.

La presentación del relato inicia con una alusión directa a una poética de la memoria: "La primera vez que recordé mi vida fue cuando se la conté a Eduardo Franco en Maní, ${ }^{2}$ en la cantina de Luis Escobar" (Molano, 2010: 25). De entrada, se percibe que el relato será una frecuente reminiscencia que va elaborándose con dos narraciones mediadas: en primer lugar, el relato que oralmente narra Berardo Giraldo a su interlocutor Alfredo Molano y, en segundo lugar, el texto literario que éste último redacta, con lo que transforma un registro oral a texto escrito. La literatura testimonial le arrebata al olvido historias que entran en directa tensión con el correlato histórico, que siempre tiene tintes de oficial e incuestionable, y lo que narra el testimonio, muchas veces, va en dirección contraria. Sin embargo, es pertinente señalar que ni la prosa de Molano, ni el relato de Giraldo, son

2 Municipio del departamento colombiano de Casanare, en la zona llanera. 
absolutamente neutrales, puesto que como lo clarificó Mijaíl Bajtín hace algunas décadas: "(...) un enunciado absolutamente neutral es imposible. Una actividad evaluadora del hombre con respecto al objeto de su discurso (cualquiera que sea este objeto) también determina la selección de los recursos léxicos, gramaticales y composicionales del enunciado" (Bajtín, 1982: 274).

En consonancia con esta postura, Roland Barthes afirma que el mito "no se define por el objeto de su mensaje sino por la forma en que se le profiere: sus límites son formales no sustanciales" (Barthes, 1999: 199). Estas dos valoraciones teóricas enfatizan la necesidad de fijar, en la dimensión estética del testimonio, el núcleo de sus estudios críticos, y utilizar la voz del narrador como elemento que, de a poco, mitifica al mismo personaje. De este modo, Berardo en su testimonio configura un origen que le permite representar la causa guerrillera y liberal por la que luchó a lo largo de su vida. Con este propósito recuerda a su madre y más que al personaje, se centra en la filiación con las ideas liberales. Realiza una oposición entre sujeto político -corrupto- y políticas liberales, para él son dos ideas radicalmente contrarias. De este modo, su trono como líder guerrillero se legitima y su linaje, cual héroe mítico, inicia su justificación:

Ellos eran políticos y yo liberal. Nací liberal. Mi mamá era la única mujer liberal que había en San Carlos, Antioquia; por eso no la querían en el pueblo. Un cura de apellido Noreña, que fue el párroco de siempre, la señalaba por atea cada vez que amanecía amargado (Molano, 2010: 36).

Giraldo viene recordando su narración de forma cronológica, pero cuando el efecto del relato requiere un poco más de información y su figura necesita datos que le otorguen relevancia, pues interrumpe la linealidad y a modo de flashback inserta pequeños relatos que aportan en su mitificación. Así, se puede ver que proviene de una madre liberal, de su padre no se tiene mención, pero eso poco importa en la configuración del mito. Este tratamiento de los orígenes también lo utiliza en la narración cuando se refiere a la figura más representativa y afamada de la guerrilla del Llano: Guadalupe Salcedo. De él Berardo afirma:

Los Undas eran primos hermanos de Guadalupe, porque la mamá de él era indígena sáliva de Arauca [...] era el jefe de todos, porque además de ser un llanerazo había prestado servicio militar y era entendido en cosa de armas. Era un negro, formal, sencillo y dominante. Cuando lo conocí $[\ldots]$ 
A mí me impresionó, no sé por qué, el Negro. Se imponía sin decir palabra (Molano, 2010: 38 - 39).

El liderazgo guerrillero de Guadalupe Salcedo, como el de Giraldo, se justifica desde el natalicio, pero además permite apreciar una relación directa de los indígenas con las ideas liberales, ambos enmarcarían un solo pueblo y la defensa de sus intereses sería crucial en la conformación de guerrillas. A la par, en el testimonio de Giraldo se puede precisar una relación con otro tipo de texto literario, que también pretende una mitificación: la hagiografía. Santiago de la Vorágine elabora la significación de la infancia de santos y mártires en su Leyenda Dorada. La estructura de este tipo de texto alude cualidades representativas para la vida religiosa sagrada desde un rasgo particular: un milagro en la infancia. Además, detalla eventos de sacrificio, que fácilmente se pueden vincular con una visión trágica de los héroes católicos, que termina legitimándolos desde el sufrimiento. En este caso, la relevancia de la infancia y las situaciones trágicas van configurando el mito del guerrillero desde sus propias palabras. Así, Berardo recuerda: "Para las elecciones de López Pumarejo ${ }^{3}$ yo tenía ya catorce años. Era un muchacho volantón más bien valentón" (2010: 37). Su valentía no sólo se menciona, para que sea creíble debe ir acompañada de algún suceso que la justifique; por lo tanto, él orquesta el relato. Berardo pertenece a una pandilla de jóvenes que cazan pájaros con balas, pero la primera confrontación armada que vive obliga a cambiar el objetivo de sus disparos hacia el enemigo que surgía: los conservadores. "De un momento a otro comenzó a caer bala, los estruendos se repetían una y otra vez. Yo disparé varias cargas sin saber a quién. Quedaron tres muertos en la plaza, todos conservadores [...] La paz que medio había se acabó" (2010: 38).

Las balas y las muertes obligaron a que la madre trasladara la familia a otra hacienda cerca de Puerto Berrío:4 "Mi mamá nunca nos quiso decir nada porque ella era una mujer muy valiente, pero en realidad a esa tierra fuimos a parar como desterrados" (2010: 39). Lejos de una concepción milagrosa prematura, propia de la hagiografía, este personaje se mitifica

\footnotetext{
3 Alfonso López Pumarejo fue presidente colombiano por el partido liberal en dos periodos: 1934 - 1938 y 1942 - 1945. La referencia en este caso obedece al primer periodo, pues el mismo Giraldo rememora que la narración se enmarca antes del año "cuarenta".

4 Municipio del departamento de Antioquia ubicado en la zona conocida como el Magdalena Medio.
} 
con un acto bélico en sus primeros años, pues su narración no es sobre un santo, es sobre un guerrillero. Pero además, su origen trágico también le permite emerger como representante del pueblo constantemente atropellado. Él fue desterrado, desplazado por la violencia, pero su madre decide volver a San Carlos: “(...) un mes después de llegar mi mamá amaneció muerta. La autopsia dijo que había sido envenenada” (2010: 38). La muerte, el destierro y su hazaña bélica infantil son características del origen de Berardo Giraldo, las cuales le permiten convertirse en líder guerrillero sin cuestionamientos. Su relato se estructura de tal forma que construye un proceso de mitificación desde la palabra, que fuera oral, pero que ahora está dentro de la rigidez de la escritura.

En la narración, los orígenes empiezan a estructurar al personaje, se abandona el flashback y se vuelve a la linealidad del relato. El envenenamiento de la madre funciona como parteaguas para situarnos en el conflicto armado. La policía emerge como enemiga del pueblo y aliada de los conservadores, sus acciones van siempre ligadas a la opresión: encarcela, golpea, maltrata e insulta, siempre a los liberales, más aún si beben alcohol:

Nos encontrábamos tomando cuando llegó la policía a cerrar a las malas el bar. Nosotros estábamos listos. Cuando dijeron manos arriba, yo levanté las manos sin acordarme que tenía dos revólveres debajo de la ruana. El que me esculcó, al toparse el revólver, gritó: “¿Esto para qué es malparido?" Yo le contesté: "Para usted... y para usted". Cayó el de aquí y el de allí (2010: 42).

Por las muertes de los oficiales deben huir rápidamente, pero su huida necesita una protección divina para salvarlos. En efecto, sucede el milagro: al llegar al río

(...) nos robamos una lancha. En aquellos nervios, con la policía dando gritos buscándonos, no atisbábamos a encontrar una cabuya para iniciar el motor. Con la ayuda de Dios, porque no fue otra cosa, encontramos una piola y arrancamos [...] Remontando el caño encontramos una familia guahiba. Nos dieron comida y hamaca (2010: 42).

Este fragmento le proporciona al lector un mensaje claro: las muertes de los policías se justifican porque ellos oprimen al pueblo; al asesino de policías Dios lo protege y los indígenas le dan asilo, pues ambos estrechan lazos desde el sufrimiento a manos del gobierno y las instituciones. Lo anterior, ratifica la heroicidad de Berardo antes de su entrada, en propiedad, a la guerrilla. 
Luego de huir acto seguido, Giraldo es capturado por un grupo insurgente, lo amarran y lo llevan ante el comandante. En su testimonio, Giraldo se apropia de la voz del comandante y recuerda que al verlo, dijo: "No, si éste es el putas. Es el Tuerto Giraldo. Suéltenlo que éste tiene más historias que todos nosotros juntos" (2010: 43). Las historias crean la fama para los guerrilleros y Giraldo lo deja claro en su testimonio, el peso de las historias enaltece al guerrillero. No obstante, sólo lo enaltece a él, porque los mismos rumores que corrían en la zona, y tenían como protagonistas a sus captores, son desmentidos. En la región se oía sobre un grupo armado, peligroso, pero quienes son, desde la mirada de Giraldo: "unos pobres catanos", los ve "temblando del susto" ante su presencia. En definitiva, los temidos guerrilleros de los rumores son unos "pobres viejitos" para la visión del único narrador testigo del relato (2010: 43).

La fama es veraz en el caso de Giraldo y es falsa en el caso de los otros guerrilleros. El "Tuerto" Giraldo saca provecho de la situación y desde su voz muestra una cualidad más del mítico guerrillero: la autoridad. Por eso, acota: "Esa vez la fama me favoreció y la aproveché ahí mismo: tomé el mando [...] Mañana me consiguen bestias antes de que aclare y me voy con usted, usted y usted a buscar los jefes, para tomarnos a Trinidad. Al ver mi autoridad, acataron mi decisión" (2010: 43).

La autoridad del líder es incuestionable como lo será su coraje y su valentía en combate, puesto que él sentencia que en la guerra la mejor defensa es el ataque, por lo que siempre hay "que jugársela toda y atacar de frente y a la brava, muriera el que muriera" (2010: 44). Claro, él nunca muere, sobrevive por los valores que relata, se erige como un vencedor y sostiene que a "los llaneros hay que saberles hablar y hay que saberlos mandar" (2010: 61). No obstante, la guerra obliga a los actores del conflicto a cometer actos censurables. Giraldo lleva asesinatos a cuestas, pero el lenguaje que utiliza pretende una afinidad con el lector; por lo tanto, selecciona las palabras para calificar sus actos. Para él, asesinar es el verbo que categoriza las muertes que hace el enemigo, mientras que las muertes que él comete se trabajan con otros términos, con eufemismos o se justifican por la lucha que los trasciende. Por ejemplo, cuando cinco civiles, colaboradores de la policía, son fusilados por una orden suya, sentencia: "Hay que eliminarlos para que escarmiente la policía y no siga creyéndo- 
nos tan pendejos" (2010: 46). La acción que parece absolutamente despreciable es inmediatamente justificada desde su testimonio: "Además, era la única forma de sacarlos de Pore. En la guerra, como en el juego, hay que poner pintas para hacer una tenida y los mandé a fusilar, en fila para no gastar sino uno o dos tiros" (2010: 46).

Igualmente, cuando hay muertes de ambos lados el uso de las palabras no es gratuito: "Mataron dos compañeros y nosotros les hicimos cinco bajas" (2010: 126). Esos detalles permiten que el mito del buen guerrillero se solidifique en la construcción del relato, pues el efecto en el lector de alguien que "mata" es más contundente comparado con el de aquel que "hace bajas". El enemigo también se construye en el testimonio, por eso su estereotipo no es gratuito. Palabras como "conservador", "militar" -ejército/policía- "abusador", "traidor", "opresor", construyen, como lo denomina Daniel Henry Pageaux, el estereotipo del enemigo; porque "el estereotipo plantea implícitamente una jerarquía constante, una verdadera dicotomía del mundo y de las culturas" (Pageaux, 1994: 108). En esa relación de jerarquía el enemigo tiene el poder estatal, pero no puede vencer al guerrillero, quien lo supera por sus condiciones físicas y sus cualidades como guerrero. De esta manera, el testimonio sitúa la figura del enemigo como el extranjero. Lo representa a través de la fobia, siempre acompañado de una visión negativa con relación a la cultura de origen, por lo que en el testimonio de Giraldo se aprecia claramente una godofobia o chulafobia, ${ }^{5}$ que lejos de generar una relación de temor ante el adversario, como el sentido mítico de la palabra lo declara, genera una férrea reacción de oposición (1994: 121).

Pero el lenguaje no sólo se usa en el relato para cuestionar las muertes ajenas y matizar las propias, también es empleado por el narrador para que los personajes contrarios a sus intereses generen un efecto de repulsión en el lector. Así continua su proceso de mitificación y jerarquía sobre sus oponentes, como sucede con el general Eliseo, quien sostiene que Giraldo es un "asesino", "violador" y "ladrón”. Estas acusaciones son de un peso significativo, sin embargo Giraldo las desmiente a través de su voz, debido a que poco a poco desdibuja la figura del comandante en jefe de las guerrillas del Llano, pues lo presenta alejado de la imagen viril de los

5 "Godos" y "chulavitas" eran los términos para referirse a los ciudadanos de filiación política conservadora y a los soldados conservadores respectivamente. Ellos, a su vez, llamaban chusma a los guerrilleros liberales: "la chusma, como nos llamaban" (Molano, 2010: 80). 
guerreros. Por eso comenta que después "del desayuno se echaba en la hamaca y no volvía a pararse hasta el otro día” (Molano, 2010: 57). Es decir, no combate, hace la guerra desde la hamaca y además es miedoso, como lo sostiene al afirmar que Eliseo no quería "salir del Llano por miedo" (2010: 63). El desprestigio sobre Eliseo hace que las palabras, en contra de Giraldo, pierdan credibilidad.

Giraldo acepta que se le haga un juicio de guerra, pero sólo con la finalidad de que su imagen siga creciendo. En su relato aprovecha el llamado a juicio para seguir desacreditando a su enemigo: "Yo ya me había olvidado, por andar en lo que andaba, del pendejo de Eliseo y sus bravuconadas. Pero él no se había olvidado de mí porque no tenía nada que hacer" (2010: 63). Se dirige al campamento del general y recuerda su llegada para seguir con su proceso de desautorización: "El viejo se encontraba echado en la hamaca" (2010: 64). Ratifica su postura de inactividad guerrillera y, acto seguido, muestra su torpeza: "Cuando me vio en la puerta se sobresaltó y quiso levantarse rápido, pero se le olvidó que estaba en la hamaca, se enredó con la espada y casi se cae al suelo" (2010: 64). El general se configura como un contrincante inferior, no tiene las cualidades que se requieren para liderar la guerrilla, así sea general.

En el juicio Giraldo es acusado con vehemencia por un fiscal de la guerrilla, pero las palabras que rememoran el episodio provienen del mismo acusado, por lo que nuevamente les agrega calificativos que desmienten cada una de las acusaciones: "Ay, Dios, qué barbaridades alcanzó a decir: que yo había violado niñas, que yo había asesinado ancianas, que yo había asaltado, robado, mentido, falsificado, traicionado, incendiado" (2010: 65). Las barbaridades se erigen en el relato como viles calumnias, no obstante, el mismo Giraldo recordará, páginas más adelante, un episodio que se relaciona directamente con las acusaciones, al menos, con los incendios: "Como la gente se metió en la iglesia a refugiarse en las enaguas del cura, me tocó sacarlos y prenderle fuego a la iglesia" (2010: 83). Pero nuevamente su responsabilidad está matizada por el lenguaje, aquí la expresión "me tocó" funciona para no asumir las consecuencias de sus actos y reafirmar que todas sus acciones obedecen a la práctica idónea de la guerra de guerrillas. De este modo, dirá también que se vio en la obligación de decretar la pena de muerte y que nuevamente le tocó dar bala, no porque fuese un sanguinario, ya que, aunque tengan la misma significación, él no asesina sino que "elimina", siempre por el bienestar co- 
mún: "Los domingos se formaban trifulcas serias y me tocaba intervenir. Tocó dar bala. Dar bala y eliminar muchos vergajos indeseables. Tuve que expulsar también al personal que no convenía con la pacificación, y me vi en la obligación de decretar la pena de muerte para mantener el orden" (2010: 140).

El juicio continuaba, la defensa de Giraldo la asumió Eduardo, personaje que en el testimonio se presenta como el ideólogo, por antonomasia, del grupo guerrillero. Es el único al que Giraldo observa como ser superior en cuanto a inteligencia. Es Eduardo quien encauza la insurgencia como la lucha del pueblo. Él es el único que habla de revolución y piensa más que todos los guerrilleros:

Yo nunca había pensado en eso. La mayoría de los guerrilleros en aquella época no pensaban tan allá. Sólo nos defendíamos. Pero Eduardo tenía más ideas, pensaba más que nosotros y nos convenció de formar el comando Monchacá [...] con ese nombre quería decir que nuestra pelea era la pelea del pueblo. Fue la primera vez que yo oí hablar de revolución (2010: 55 - 56).

Pero en la estructura del relato, la sapiencia de Eduardo tiene un rol trascendental, pues como es más inteligente que el resto, sus palabras son incuestionables. Por lo tanto, en la defensa de Berardo la inteligencia de Eduardo funciona como elemento contundente para la mitificación del capitán, de quien dice: "No hay tacha en la hoja de vida de mi defendido, es cristalina como el agua del Llano, diáfana como su luz, despejada y abierta como sus horizontes" (2010: 66). Del mismo modo, su peso ideológico le permite recriminar: "Yo sólo puedo declarar que la mayoría de las cosas que el señor fiscal ha dicho constituyen una enorme montaña de mentiras, asquerosas y repugnantes" (2010: 66).

El juicio concluye y Giraldo, quien tuvo que humillarse al ser amarrado, obtiene mayor aceptación en el grupo, pues su humillación fue por la causa, por eso afirma: "Yo tenía mi plan y mi plan pasaba por esa deshonra” (2010: 64). De allí sale más enaltecida su imagen; además, Eduardo no sólo desmiente las acusaciones, también refiere hazañas de su defendido, menciona sus habilidades en combate, su gallardía, su fortaleza, su tenacidad. Eliseo escucha y concluye en contra de Giraldo: "Todo bandido es de buenas" (2010: 62), pero en esta instancia del relato las palabras de Eliseo ya han perdido todo su peso argumentativo. 
Para finalizar el episodio del juicio, Giraldo arremete y cuestiona el grado de general de Eliseo. Los grados en la guerrilla del Llano llegan por la antigüedad en la militancia, por los combates y por designación popular. Por eso Eliseo era General y Giraldo Capitán, pero este último reconoce sólo su capitanía y afirma que Eliseo no es su General, en consonancia dirá: "Yo soy Berardo Giraldo, capitán del Llano, y vengo a buscar la paz por las buenas o por los malas, si prefieren. Vengo a imponer el orden, a terminar el robo, a perseguir a los asesinos que han impuesto su ley, a buscar que todo el mundo tenga trabajo" (2010:114). Luego, sostendrá que él "era un liberal que no tenía sino un pecado y era defender el Ariari ${ }^{6}$ y que por eso la gente me quería, me respetaba y me llamaban capitán" (2010: 150). Su grado se ratifica desde su voz, y así debe ser para que su mitificación se consolide, pues según las palabras de Bronislaw Malinowski, el mito "expresa, realza y codifica las creencias; salvaguarda los principios morales y los impone" (Malinowski, ctd., en: Eliade, 1963: 26). De esta manera, el mito del buen guerrillero, relatado por Giraldo, define un perfil de comportamiento, hace las veces de manual guerrerista, moralista, ejemplarizante y hasta caballeresco, ya que el mismo que dispara, lucha e incendia en pro de la revolución, también es un galante respetuoso de las mujeres, puesto que en pleno combate deben resguardarse en el convento del pueblo de Nunchía. ${ }^{7}$ Allí le gusta una "monjita", pero no se sobrepasa y utiliza la primera persona del plural para dar cátedra y generalizar el buen comportamiento insurgente ante la presencia de las monjas, por eso recuerda: "nosotros todos muy respetuosos" (Molano, 2010: 72).

Su imagen se engalana de caballerosidad y presenta, desde sus actos, la forma idónea de comportamiento del guerrillero revolucionario, no sólo en combate, sino en las diversas facetas de la lucha armada. Lo anterior permite traer a colación, nuevamente, la postura de Daniel Henry Pageaux sobre la imagen, que aquí se dibuja con palabras y simboliza la realidad guerrillera, pues “(...) la imagen es la representación de una realidad cultural mediante la cual el individuo o el grupo que la ha elaborado (o que la comparten o que la propagan) revelan y traducen el espacio cultural e ideológico en el que se sitúan" (Pageaux, 1994: 101).

\footnotetext{
6 Zona en la que convergen diferentes municipios del departamento del Meta y que se ubica dentro del territorio del Llano colombiano.

7 Municipio colombiano situado en el departamento del Casanare dentro de la zona del Llano.
} 
Ligado a este proceso de mitificación, el uso del lenguaje adquiere una mayor representatividad, debido a que el testimonio contiene en sí mismo esa intención de verdad, mediada, sin lugar a dudas, pero verdad al fin y al cabo. El uso de un lenguaje popular le permite a Giraldo continuar con su proceso de mitificación, y el autor, Alfredo Molano, hace un trabajo muy respetuoso del registro, ya que él mismo afirma que no existe una pretensión de verdad absoluta que se erija como universal, sino que "cada personaje tiene su verdad y es víctima de ella. Está consignada en su propio interés y ello es respetable y debe ser respetado en una historia" (Molano, 2010: 11). El lenguaje popular se relaciona directamente con la denuncia del pueblo, con los intereses de los oprimidos y por supuesto con el mito, pues si se debe señalar una cultura como originaria de la visión mítica, la cultura popular asume ese reto con legitimidad absoluta, al menos, en Latinoamérica.

Así, entre palabras autóctonas y juegos discursivos, los refranes y dichos tienen una relevancia particular en el registro oral, que no se pierde en el texto escrito y que ubica de manera sociocultural a su emisor, Giraldo, quien usa de forma natural los dichos populares. Usa, por ejemplo, para aludir un evento positivo: "El pueblo estaba rodeado de selva y había muy buenos maderales. Así que dijimos: aquí cayó Jesús, y montamos el aserrío" (2010: 29 [Cursivas mías]). Para rememorar un mal día: "Hay días en que uno no amanece para hacer natilla" (2010: 36). Para recordar a un contrincante indigno de él: "A mí no me pasaba por la cabeza ponerme a gastar pólvora en gallinazo" (2010: 50 [Cursivas mías]) y para relatar una cambio de una situación buena a una desfavorable: "La cosa estaba ganada. Pero entonces se nos volteó el Cristo" (2010: 73 [Cursivas mías]).

El uso de este tipo de lenguaje popular, en la voz del personaje-narrador, marca dos efectos significativos en la configuración del relato: el primero, obedece a una ética de la forma que hace más veraz la configuración del personaje, pues si hablara de otro modo, su intención de veracidad fallaría, por eso se justifican algunas modificaciones sintácticas y el uso constante de expresiones coloquiales; y en segundo lugar, permite visualizar una dimensión estética narrativa que respeta las características del testimonio y que en la perspectiva bajtiniana, lo ubica como uno de los géneros discursivos complejos, puesto que la narración testimonial absorbe diversos géneros discursivos simples o primarios: 
Los géneros discursivos secundarios (complejos) -a saber, novelas, dramas, investigaciones científicas de toda clase, grandes géneros periodísticos, etc.- surgen en condiciones de la comunicación cultural más compleja, relativamente más desarrollada y organizada, principalmente escrita: comunicación artística, científica, sociopolítica, etc. En el proceso de su formación estos géneros absorben y reelaboran diversos géneros primarios (simples) constituidos en la comunicación discursiva inmediata (Bajtín, 1982: 251).

El lenguaje popular funciona, en este caso, no sólo como elemento primordial en la construcción del relato, sino también como característica imprescindible en la mitificación del personaje. Igualmente, el testimonio, a modo de discurso familiar y de conversación directa, adquiere un efecto de veracidad propio del género, pues se construye bajo los parámetros de sinceridad de plaza pública y siempre llama las cosas por su nombre, lo que directamente el lector relaciona con una historia verdadera (1982: 287).

El lenguaje autóctono también representa la cultura de origen, en este caso del pueblo tanto indígena como campesino, y en esa perspectiva de autenticidad, la naturaleza y la región que conforman el ámbito cultural del guerrillero, favorecen la mitificación del capitán Giraldo. Él se vale de la naturaleza para curar las heridas de guerra y reponerse, mientras que la región favorece a los combatientes del Llano, en contraste con los foráneos del ejército oficial que sufren. Ante los bombardeos aéreos incesantes, Giraldo menciona el uso de armas químicas por parte del ejército: "Soltaban unas bombas que desperdigaban una gelatina negra ácida que hacía llaga primero y después hueco. Eran armas prohibidas. Pero, ¿dónde poníamos el denuncio?" (Molano, 2010: 85). En este contexto, el dominio de los componentes naturales es crucial para sobrellevar este ataque inhumano, la naturaleza es aliada de los héroes mitológicos y el relato lo deja claro:

Contra las bombas descubrimos que el jugo de limón asado, aunque doliera terriblemente, curaba las llagas; contra la fiebre encontramos secretos y los rezos que los indios utilizaban: yerba contragavilanes, verbena y aguardiente en ayunas; contra los morteros surales; contra la falta de ropas y calzado, cuero crudo machacado; y contra la falta de sal, de panela y de café, una excursión a Támara (Molano, 2010: 86).

Pero no sólo la naturaleza cumplía su parte para defender a los guerreros, la geografía también se manifestaba a favor de los guerrilleros y en contra del ejército, como lo recuerda Giraldo: 
Una patrulla de tres o cuatro era suficiente para inmovilizarlos. A donde íbamos los atajábamos y cuando queríamos los dejábamos caminar hasta agotarse. No conocían el Llano, eran soldados traídos de la cordillera, de Caldas, de Nariño. Gente acostumbrada a mirar cerquita y caminar con las rodillas. El Llano abierto les daba desconfianza y miedo. Los obligamos a no poder moverse. Su cárcel eran los meros horizontes abiertos, y eso los desmoralizó (2010: 95).

De igual forma, la lucha que representa Giraldo cuenta con la participación de todo el pueblo. Niños, mujeres, ancianos y hombres cumplen su función en la guerra, por eso el mito de Giraldo pertenece a la comunidad originaria, porque todos participan del conflicto desde el bando que lidera el capitán:

Todos eran necesarios y útiles. Los niños eran expertos minadores y sabían tirar de los espolones como si fuera el viento mismo. Las mujeres cocinaban y conseguían para cocinar; defendían sus hijos, cuidaban sus hijas y animaban a los hombres. Todos tenían un sitio. Los viejos hacían caminos secretos que sólo nosotros conocíamos. La viejas (sic) hacían manilas, recargaban cartuchos. La agitación se nos metió en los huesos, y no había momento de descanso (2010: 94).

El pueblo vinculado con la lucha guerrillera certifica la mitificación de Giraldo. Pero la dinámica trágica del conflicto armado tiene sus momentos decadentes; golpeado por el asesinato de Guadalupe Salcedo en Bogotá, Giraldo se siente derrotado, sin ánimo de seguir luchando y, cuando todo parece resquebrajarse, el clamor del pueblo es el que lo hace volver a tomar las armas. El pueblo requería un héroe y Giraldo nuevamente tomó las riendas del combate. Por eso, le insistían: "Capitán, usted no puede abandonarnos ahora. Si usted se va nos come el tigre. Esto vuelve hacer tierra de nadie porque aquí no aceptamos al ejército. Si no es usted, que no sea nadie" (2010: 132). La voz del pueblo, que se conoce como la voz de Dios, ratifica el mito del buen guerrillero. Además, un rasgo particular de los héroes de la revolución es la musicalización de sus vidas y hazañas. El corrido mexicano inmortalizó a los representantes de la revolución y, en este caso, la música llanera lo hace con Giraldo. Él recuerda unos versos que le compusieron en su honor, con la finalidad de que no abandone la lucha, pero además aportan de forma crucial en su configuración como personaje y, por supuesto, en la hipótesis de lectura sobre su proceso de mitificación: 
A La Playa venimos de Canaguaro $y$ venimos a cantar este joropo del Llano; $y$ vamos, muchachos, vamos a cantar este joropo sentido, dedicado al capitán.

De las tropas guerrilleras también les vengo a contar que lucharon por la causa del Partido Liberal.

Vamos, muchachos, vamos a cantar con la voz d nuestro pecho que Giraldo, el capitán, demostró ya su valor con sus valientes armados recobrando nuestro honor (2010: 133 - 134).

Por lo anterior, se desprende que la lucha no es individual: es colectiva y popular. Por eso, Giraldo afirma: "Me hicieron desistir. Yo comprendí que me necesitaban y que estaban en lo correcto" (2010: 134). Del mismo modo, en el testimonio, la imposibilidad de asesinar a Giraldo realza su figura mítica, pues siempre se salva de los atentados, de las emboscadas, y sale airoso de las situaciones más peligrosas: "Quedé entre tres líneas de fuego [...] seguía en un peligro el verraco" (2010: 73). Su fama hace que mueran inocentes cuando sus enemigos pretenden asesinarlo, él lo deja ver en su narración con fuerte contenido de humor negro, que le permite sentirse nuevamente superior, mientras se mofa de sus perseguidores: "(...) un domingo a la salida de misa, en el atrio mismo, asesinaron a una señora tuerta y embarazada porque dizque era yo disfrazado. No se les ocurrió pensar que todo podía estar haciendo yo menos oyendo misa" (2010: 86).

En los actos de combate, también él origina las tácticas de guerra para vencer al enemigo. Con los ataques aéreos los guerrilleros enfrentan algo que no tenían previsto: combatir hacia arriba. Pero Giraldo vence una vez más:

Yo dije: 'Hay que perderles el miedo a los aviones'. Llamé a cinco, les ordené hacer con los mejores fusiles una sombrilla y les dije: 'Cuando venga de para abajo, hagámosle el tiro unos cinco metros adelante del motor a ver que pasa'[...] y sí señor, el chorrito de humo. Quedó volando como borracho y fue a caer cerca a Yopal ${ }^{8}$ [...] El impacto destrozo el avión (2010: $81-82)$.

8 Capital del departamento del Casanare en la zona del Llano colombiano. 
La relevancia de este fragmento se percibe en la trascendencia del mito de Giraldo, que está ligado al lenguaje popular, a la geografía, a la naturaleza, a los valores del guerrillero, al compromiso con la causa y a la afinidad característica entre la guerrilla y el pueblo originario. Él, como lo propone Mircea Eliade, se mitifica en su narración, porque evoca los comienzos de una historia relevante, en este caso los inicios de la guerrilla colombiana. Eliade, en busca de una definición lo menos equivoca sobre mito, decide utilizar la siguiente, que encaja en la hipótesis de lectura que se viene trabajando, porque el mito

(...) cuenta una historia sagrada; relata un acontecimiento que ha tenido lugar en el tiempo primordial, el tiempo fabuloso de los 'comienzos'. Dicho de otro modo: el mito cuenta cómo, gracias a las hazañas de los Seres Sobrenaturales, una realidad ha venido a la existencia, sea ésta la realidad total, el Cosmos, o solamente un fragmento: una isla, una especie vegetal, un comportamiento humano, una institución [...] Los personajes de los mitos son Seres Sobrenaturales. Se les conoce sobre todo por lo que han hecho en el tiempo prestigioso de los 'comienzos' (Eliade, 1963: 14).

Giraldo no representa el mito originario de la creación, pero sí enmarca el mito de los orígenes del conflicto armado en Colombia, al menos, el de la lucha de guerrillas. No importa si tuvo que disparar y si de esas balas hubo muertos. Tampoco si minó campos para acabar con el enemigo, como lo deja entrever al afirmar que en Pajarito9

(...) se desocupó el pueblo y se dejó minado. El ejército no podía andar tranquilo. Todo estaba conectado con espolones: los naranjos, los mates de yuca. Los caminos eran un calvario. Los tanques no pudieron llegar. Hubo cantidad de muertos y de heridos. Un soldadito con sed iba a coger una naranja y ¡tan! Iba a coger una mata de yuca y itan! Abrían la puerta de un rancho y ¡tan! (Molano, 2010: 93)

Lo absurdamente criminal que resultan las minas antipersona, y que tanta sangre han hecho derramar a los colombianos, se presenta como una táctica que se aplaude en la estrategia de guerra: lo más importante es vencer al enemigo, y para ello, cualquier método es bien visto, así sea sanguinario. En su narración también se advierte que Giraldo, en su proceso de mitificación, demarca los principios fundacionales de la guerrilla y su conducta, por eso afirma: "Siempre fui muy cuidadoso, siempre respeté

9 Municipio de paso entre la carretera que comunica Bogotá con los Llanos Orientales y que pertenece al departamento de Boyacá. 
los bienes de todo el mundo, porque en parte por eso luché. Yo tuve que fusilar por robo. Las leyes del Llano eran en eso muy duras" (2010: 111).

En su relato no se le escapa ningún detalle, por eso se muestra como amante de los caballos, que son sus fieles acompañantes en las acciones heroicas. Lo cual no podría ser de otra manera, porque la tradición así lo requiere, como lo reflejan las figuras míticas de Bolívar y San Martín, que se alzan en el arte ecuestre para rememorar las gestas desde estatuas que se resisten a olvidar las historias, mientras decoran plazas por toda la geografía latinoamericana. De esta forma, Giraldo menciona que él tenía los mejores caballos del Llano como "Jalisco, un alazán de paso fino; a Tornillo, un moro; a El Viento, un trochador ligero, y a Gavilán, que era puro nervio, un pedazo de mi cuerpo" (2010: 141). Al profesar su afinidad equina, se asemeja a las figuras más representativas de las luchas de los pueblos oprimidos del continente y da cuenta de una tradición guerrerista que representa, con creces, desde su relato.

DOS FALSOS PROBLEMAS DEL TESTIMONIO: HABLAR CON LA VERDAD Y DAR $\mathrm{VOZ}$

De lo anterior, se desprende un problema recurrente en la literatura testimonial: lo que allí se narra es verdad. Esta tensión entre verdad y mentira hace las veces en el género testimonio del falso problema entre objetividad y subjetividad, perteneciente a otros géneros discursivos. Es fundamental añadir que no existe ni existirá una sola verdad, las historias son verdades propias de quien las emite. Por eso la mitificación guerrillera que hace Giraldo no puede cuestionarse desde la oposición maniquea verdad/mentira, porque lo que allí se consigna obedece a un relato que da cuenta de una realidad histórica verdadera. Valga recordar la pertinencia de Jacques Rancière al respecto de este falso problema: "La revolución estética revuelve las cosas: el testimonio y la ficción participan de un mismo régimen de sentido" (Rancière, 2009: 272). Y en cuanto a quienes descalifican la escritura de historias de forma gratuita, en favor del correlato histórico oficial, el filósofo francés arguye: "Escribir la historia o escribir historias participan de un mismo régimen de verdad" (2009: 273)

Así, pues, el grado de verdad que tiene el testimonio de Giraldo es el mismo grado de verdad que tiene el correlato histórico, con el cual dialoga. Por otra parte, la literatura testimonial permite apreciar una actitud 
paternalista en la estructura académica, pues se suele afirmar que le da voz al que no tiene voz. Lo cual es problemático, pues el mismo testimonio contiene la voz del narrador. Es en sí mismo oral, Giraldo tuvo siempre voz, antes de conocer a Molano, lo que se debe precisar es que el trabajo del autor le permite al testimonio de Giraldo obtener las credenciales expeditas para que otras esferas conozcan su historia.

Es, en esta dirección, que se puede valorar el trabajo del escritor, porque a través de su texto permite que una realidad se conozca en círculos sociales indiferentes y divergentes al contexto de origen, que se caracteriza por un analfabetismo generalizado. El mismo Giraldo lo presenta y lo utiliza para relacionarse con otras luchas de guerrillas en el continente, pero al mismo tiempo, para demarcar la particularidad del movimiento que representa:

Nosotros todos éramos analfabetos. Los Bautistas eran peleadores bravos, Guadalupe un llanero arisco. No habíamos leído nada. En vez de armas, la Dirección Nacional Liberal nos había mandado de regalo una vez dos libros: uno sobre la revolución mexicana y otro sobre la revolución de Nicaragua. Nos gustaron Zapata y Sandino. Habían estado en las mismas nuestras, pero hasta ahí (Molano, 2010: 96).

La literatura testimonial permite que se configure un personaje arquetipo con características singulares que obedecen al conflicto en el que intervino. Así, pues, resulta sencillo entablar un diálogo con otro testimonio surgido de las pugnas en Bolivia contra los opresores del pueblo, en especial del pueblo minero. En este contexto, Domitila Barrios, personaje analizado por Antonio Cornejo Polar, se erige como representante de su comunidad y, como Berardo Giraldo, narra

(...) desde una situación de liderazgo que reorganiza todas las vivencias y las proyecta como experiencias formativas que casi inevitablemente conducen (y legitiman) su rol dirigencial [...] rol que implica una muy cabal representación de los otros (que tienen los mismos ideales y han sufrido igual $[\ldots]$ ) una ética invulnerable (jamás los traicionará $[\ldots]$ ) y una vocación heroica y hasta martirológica (Cornejo Polar, 1994: 203).

Desde esta mirada, la literatura testimonial configura su personaje central, pero también inicia un proceso en el que surge un nuevo sujeto épico, ligado siempre a la mitificación desde el relato oral, donde se construye con rasgos peculiares y necesarios para desempeñar su rol trascendental en la historia. Tal como lo establece Juan Duchesne Winter quien, al estu- 
diar este nuevo sujeto épico, afirma que el testigo guerrillero lucha por "la necesidad de la violencia revolucionaria” (Duchesne, 1992: 112). Su configuración surge de cinco puntos clave: "(1) la actitud en el combate; (2) la conducta hacia los demás guerrilleros; (3) la resistencia física y sicológica; (4) el desafío de la naturaleza y (5) las relaciones con los campesinos y otros habitantes de la zona" (1992: 111).

Estas características son claras en el proceso de mitificación que Berardo Giraldo hace de sí mismo, pero además, el testimonio tiene otra peculiaridad que le permite al testimoniante pasar de ser un sujeto individual a un sujeto colectivo. Esta precisión también la refiere Cornejo Polar, quien arguye que un testimonio clásico es aquel en el que

(...) el narrador originario asume la representación global de un grupo humano oprimido, y en esa misma medida se obliga a constituirse como un sujeto fuerte y estable, dentro de un proyecto que es tanto político [...] cuanto, por decirlo de alguna manera, utópico redentor (después de todo el sufrimiento personal y grupal tendrá que dar sus frutos en el futuro) (Cornejo Polar, 1994: 203).

De este modo, un tipo de hacer literatura -testimonio- genera un nuevo tipo de personaje literario -testimoniante-. En el caso de Giraldo, además de asumir la voz de un grupo particular, también hace las veces de narrador omnisciente, porque él se interna en la conciencia de los personajes, sabe lo que pensaron, lo que sintieron, y esto legitima aún más su proceso de mitificación. Lo cual también es una característica de la literatura testimonial, pues el testigo que narra se aleja de la figura del testigo integral que propone Giorgio Agamben, pues más allá de que hable con su verdad y de que construya memoria histórica desde la literatura:

(...) el testimonio vale en lo esencial por lo que falta en él; contiene, en su centro mismo, algo que es intestimoniable, que destruye la autoridad de los supervivientes. Los 'verdaderos testigos', los 'testigos integrales' son los que no han testimoniado ni hubieran podido hacerlo (Agamben, 2005: 34).

\section{A MODO DE CONCLUSIÓN}

El proceso de mitificación de Berardo Giraldo, desde su testimonio, configura un personaje con características particulares de la literatura testimonial. Su valentía en combate, su galantería, su relaciones con el pueblo, la geografía y la naturaleza, lo ubican como un ser ejemplar y ejemplarizante 
en el origen de la guerrilla del Llano. Desde una perspectiva mitológica el testimonio de Giraldo le permite convertirse en el ser sobrenatural protagonista de su propio mito.

Giraldo no sólo habla por sí mismo, sino que desde su testimonio se apodera de las voces de los testigos integrales, para recordar sus vidas y arrebatarle sus historias al olvido. Él sobrevivió, los otros perecieron, por eso asume su responsabilidad de testimoniar, mientras demarca el modelo de conducta guerrillero. El lenguaje popular, los recursos literarios, la ascendencia liberal e indígena, la valentía guerrerista y el arte ecuestre conforman, en primer lugar, la dimensión estética de la narración, que a su vez configura una apropiada ética de la forma; y en segundo lugar, le otorgan un efecto claro de veracidad al personaje testimoniante, que dialoga con las imágenes de los líderes insurgentes y emblemáticos de Latinoamérica.

Finalmente, es pertinente señalar que la mitificación de Giraldo se logra gracias al texto literario, pues la literatura garantiza la supervivencia del mito, que en las formas literarias muta, cambia, pero no desaparece. El Odiseo guerrillero narró su mito para que el Homero colombiano lo plasmara por escrito. Por lo tanto, él y su relato representan el mito del buen guerrillero, al menos, dentro del conflicto en Colombia.

\section{BIBLIOGRAFÍA:}

AGAMBEN, G. (2005); Lo que queda de Auschwitz, El archivo y el testigo. Homo Sacher III. Valencia: Pre-textos.

BAJTíN, M. (1982); Estética de la creación verbal. México D.F.: Siglo XXI.

BARTHES, R. (1999); Mitologías. México D.F.: Siglo XXI.

CORNEJO POLAR, A. (1994); Escribir en el aire: ensayo sobre la heterogeneidad socio-cultural de las literaturas andinas. Lima: Horizonte.

DUCHESNE WINTER, J. (1992); Narraciones de testimonio en América Latina. Rio Piedras: Editorial de la Universidad de Puerto Rico.

ELIADE, M. (1963); Mito y realidad. Barcelona: Editorial Labor.

FALS BORDA, O. (2010); “Prólogo". En: Alfredo Molano, Siguiendo el corte. Relatos de Guerras y de Tierras. Bogotá: Punto de Lectura, 13-21.

MOLANO, A. (2006); Los años del tropel. Crónicas de la violencia. Bogotá: Punto de Lectura.

(2010); Siguiendo el corte. Relatos de Guerras y de Tierras. Bogotá: Punto de Lectura. 
PAGEAUX, D. (1994); “De la imaginería cultural al imaginario”. En: Pierre Brunel e Yves Chevrel (ed.), Compendio de literatura comparada. México D.F.: Siglo XXI, $101-132$.

RANCIĖRE, J. (2009); “De las modalidades de la ficción”. En: Francoise Perus (Coord.), La historia en la ficción y la ficción en la historia: reflexiones en torno a la cultura y algunas nociones afines: historia, lenguaje y ficción. México: UNAM-Instituto de Investigaciones Sociales, $269-275$. 
